\title{
Vegetative Growth and Flowering of Young Apple Trees in Response to Prohexadione-calcium
}

\author{
Christopher L. Owens ${ }^{1}$ \\ Department of Fruit and Vegetable Science, Cornell University, Ithaca, NY 14853 \\ Ed Stover ${ }^{2}$ \\ Department of Horticultural Science, Cornell University, P.O. Box 727, Highland, NY 12528
}

Early and consistent cropping of new apple plantings typically depends on orchard management to balance the vegetative and reproductive growth of young trees (Forshey and Elfving, 1987). Ideally, young trees will quickly fill allotted orchard space and then rapidly switch to a reproductive state.

Large nursery trees usually grow more quickly than smaller trees. As a result, they command a premium price, encouraging aggressive tree growth by nurseries. Large size of planting stock often necessitates heading cuts, either to facilitate shipment, or at planting to bring roots and shoots into balance, and heading cuts reduce early cropping (Marini et al., 1993; Parker and Young, 1995). Use of chemical defoliants on actively growing trees is a routine practice in many nurseries to facilitate tree storage before risk of cold injury (Chen et al., 1991; Larsen and Fritts, 1986), but this practice can reduce early vegetative growth and yields (Abusrewil et al., 1983; Batjer and Westwood, 1963).

If nursery production practices could be altered so that the trees entered dormancy more gradually, several advantages might be realized. Earlier terminal bud set could enhance storage carbohydrate and nitrogen reserves, possibly overcoming the poor spring growth associated with use of chemical defoliants (Abusrewil et al., 1983). Also, stopping extension growth of the nursery trees earlier in the season could divert tree resources into greater growth in caliper, the main factor in nursery stock grade, and could eliminate the need for heading cuts at planting, which might bring trees into production faster. Earlier terminal bud set in the nursery might also lead to earlier and more gradual onset of dormancy and decrease the risk of cold injury.

Economic studies have demonstrated the marked advantages of early fruit production (Peterson and Hinman, 1994). As a result, many techniques are used to accelerate flowering in young orchards; dwarfing rootstocks, branch bending, and minimal pruning are routinely used for this purpose (Westwood, 1993). Some cultivars, however, are slow to bear and additional methods to increase flowering in young orchards are desirable (Preston, 1978).

In apple, gibberellins (GAs) have often been implicated in both stem elongation and flower inhibition (Rademacher, 1991). As a result, researchers have evaluated inhibitors of GA-biosynthesis as tools for restricting vegetative growth or shifting the balance from vegetative growth to cropping. Compounds that have been tested for such purposes include chlormequat [(2-chloroethyl) trimethylammonium chloride], daminozide (succinic acid 2,2dimethylhydrazide), and paclobutrazol $\{\beta-[(4-$ chlorophenyl)methyl]$\alpha$-(1,1-dimethyethyl)-1H-1,2,4-triazole-1-ethanol \} (Edgerton, 1986; Quinlan and Richardson, 1984; Steffens et al., 1992; Williams, 1983). Although these compounds inhibit stem elongation and sometimes promote flowering in apple, they have the disadvantages of extended persistence in trees, troubling toxicological properties, and/or public concern over their use (Curry and Williams, 1983; Greene, 1986; Steffens and Wang, 1986). However, results from experimental use of GA inhibitors in apple have been promising and the interest in their use for fruit production has continued.

Received for publication 23 Sept. 1998. Accepted for publication 3 Nov. 1998. The cost of publishing this paper was defrayed in part by the payment of page charges. Under postal regulations, this paper therefore must be hereby marked advertisement solely to indicate this fact.

${ }^{1}$ Current address: Dept. of Horticulture, Michigan State Univ., East Lansing, MI 48824-1325.

${ }^{2}$ Current address: Univ. of Florida, Indian River Research \& Education Center, 2199 S. Rock Rd., Ft. Pierce, FL 34945-3138.
Prohexadione-calcium [(P-Ca); BAS-125W (3-oxido-4-propionyl5-oxo-3-cyclohexene-carboxylate)] is an experimental GA-biosynthesis inhibitor with low toxicity and limited persistence. In apples, P$\mathrm{Ca}$ induces terminal bud set $\approx 2$ weeks after application and is totally metabolized within 4 to 5 weeks following terminal bud set (Evans et al., 1997). The objectives of this research were to test the hypotheses that 1) P-Ca applied to apple nursery stock in early fall will enhance accumulation of nonstructural carbohydrates and $\mathrm{N}$ and improve subsequent orchard growth; and 2) application of $\mathrm{P}-\mathrm{Ca}$ will promote flowering in young orchards.

\section{MATERIALS AND METHODS}

Treatments to determine P-Ca effects on apple nursery stock were applied in a commercial nursery in Wolcott, N.Y. Forty uniform nursery trees each of the cultivars Gibson Golden Delicious/M.9 and Sun Fuji/M.9 with three or four well-developed (>20 cm in length) lateral branches were selected. The experiment was established as a randomized complete block design, with blocking based on field location. Ten single-tree replications were selected to receive each treatment. Applications of P-Ca were made with a backpack sprayer to run-off, at $250 \mathrm{mg} \cdot \mathrm{L}^{-1}$. Treatments were a nontreated control, application 1 Sept. 1996, application 1 Oct. 1996, and applications on both dates.

Terminal bud set on both the leader and the lateral branches of each tree was monitored at weekly intervals beginning 16 Sept. 1996. Unexpectedly, on 14 Oct. 1996, a chemical defoliant, DEPEG (polyethyleneglycoldodecyl ether) at $2.4 \mathrm{~mL} \cdot \mathrm{L}^{-1}$ plus dimethipin $(2,3-$ dihydro-5,6-dimethyl-1,4-dithiin 1,1,4,4-tetraoxide) at $3.12 \mathrm{~mL} \cdot \mathrm{L}^{-1}$, was applied across all treatments by the nursery. Since all trees were treated uniformly, the relative results of P-Ca treatments should be valid, although the time allowed for treatment effects was reduced.

After defoliation, the trees were dug and placed in cold storage at the nursery. The 'Golden Delicious' were dug on 4 Nov. and the 'Fuji' on 12 Nov. 1996. Root systems were moistened and wrapped in plastic, and the trees placed in cold storage $\left(4-5^{\circ} \mathrm{C}\right)$. On $15 \mathrm{Feb} .1997$, tissue samples were collected from all trees for carbohydrate determination. Tissue sampling was conducted by removing $15-$ to $20-\mathrm{cm}$ sections from the tips of three or four lateral branches plus the leader. Four or five root samples were collected from storage roots that closely approximated the shoot samples in diameter. Samples were ground to a fine powder, and soluble sugars were extracted with hot ethanol. The extract was centrifuged, passed through a cation-anion exchange column, and the sugars were quantified using gas chromatography $(\mathrm{Li}$ et al., 1982). The pellet was resuspended in water, held at $90{ }^{\circ} \mathrm{C}$ until the starch gelled, and glucose was assayed colorimetrically after hydrolysis of starch to glucose [using a microplate reader (Benchmark Microplate Reader, Bio-Rad, Hercules, Calif.)] (Li et al., 1982). Samples were submitted to Cornell Univ.'s tissue nutrient analysis lab for $\mathrm{N}$ content determinations.

Following tissue sampling for carbohydrate analysis, trees were kept in storage until 21 Apr. 1997, then planted at the Hudson Valley Laboratory in Highland, N.Y., using a randomized complete-block design. All trees still possessed at least three lateral branches $>10 \mathrm{~cm}$ in length. After budbreak, all emerging shoots were rubbed off except the new shoot in the most apical position of the leader and each major branch. On both 1 June and 5 Aug. 1997, current-season shoot growth was measured on the leader and the most apical shoots on the three largest lateral branches. 
In 1996, a second experiment, to evaluate effects of P-Ca on early flowering, was established using trees of three apple cultivars ('Macoun'/M.9/MM.111, 'Ace Spur Delicous'/M.26, and 'Sun Fuji'/ M.9/MM.111) entering their second leaf. Trees were located at two commercial orchards in Clintondale, N.Y. The 'Macoun' were at one site, and the other two cultivars at the other site. Each site was managed separately by grower cooperators using routine orchard practices. Sixty-four trees of each cultivar with at least three well-developed scaffold branches were selected. The experiment was established as a randomized complete-block design, with trunk cross-sectional area serving as the blocking criterion. Eight single-tree replications of eight treatments were established for each of the three cultivars. The treatments consisted of P-Ca applications made at $250 \mathrm{mg} \cdot \mathrm{L}^{-1}$ on the following dates: 17 June, 3 July, 17 July, 3 Aug., 17 Aug., 3 Sept., and 17 Sept. 1996. Times of terminal bud set and renewed apical growth were monitored throughout the 1996 growing season. Total seasonal shoot growth and node development were assessed for each tree during the dormant season. On 4 May 1997 the total number of flower clusters per plant was recorded for both previous season's growth and all other wood in each tree. On 15 June 1997 the total number of fruit on each plant was counted for all trees. 'Macoun' was chemically thinned (600 $\mathrm{mg} \cdot \mathrm{L}^{-1}$ carbaryl plus $1 \mathrm{mg} \cdot \mathrm{L}^{-1}$ naphthaleneacetic acid) on 20 May 1997. 'Delicious' and 'Fuji' were not chemically thinned.

\section{RESULTS}

The leaders of nursery trees treated with P-Ca on 1 Sept. displayed significantly more bud set than did those of nonsprayed trees by 23 Sept. 1996 (Table 1). Terminal bud set was induced by P-Ca $\approx 3$ weeks before normal bud set for the leaders in both 'Fuji' and 'Golden Delicious' and 2 weeks before bud set for the lateral branches of 'Fuji' trees (data not shown). 'Golden Delicious' showed no effect of P-Ca on terminal bud set in lateral branches, but all buds had set on nontreated trees by 23 Sept. When P-Ca was applied to nursery trees on 1 Oct. 1996, half the terminal buds on the lateral branches of the control trees had already set on 'Fuji', and all had set on 'Golden Delicious' (Table 1). Terminal buds of the control leaders had set in $10 \%$ of the 'Golden Delicious' and none of the 'Fuji' on 1 Oct.

Midwinter nonstructural carbohydrate and $\mathrm{N}$ contents of 'Golden Delicious' shoots were enhanced by P-Ca treatment, with the early treatment producing the greatest effects (Table 2). No P-Ca effect was observed on carbohydrate concentration in root samples of either 'Fuji' or 'Golden Delicious' (data not shown) or in the shoots of the
'Fuji' trees. Nitrogen levels were increased by P-Ca in the shoots of both cultivars, but not in the roots (data not shown).

No effect of P-Ca was observed on 'Fuji' shoot growth, but in 'Golden Delicious' multiple comparison indicated 22\% greater shoot growth in P-Ca treated trees than in nontreated controls by 5 Aug. 1997 (Table 2). Regressions for individual trees showed no correlation between spring shoot growth and carbohydrate or $\mathrm{N}$ levels for either cultivar (data not shown).

Prohexadione-Ca also induced early terminal bud set when applied to actively growing shoots of second-leaf trees. The 'Macoun' trees were well irrigated for the entire 1996 growing season, resulting in active shoot elongation on the nontreated trees for most of the season. Typically, terminal buds developed 2 weeks after treatment with all PCa concentrations. 'Macoun' trees receiving the two earliest treatments, 17 June and 3 July, resumed growth approximately 1 month after terminal bud set, while trees treated on 17 July and later often showed swelling of terminal buds, but no shoot growth.

The effects of P-Ca on 'Macoun' shoot growth were proportional to earliness of application, with significant growth reduction from treatments applied 17 June to 3 Aug. (Table 3). Elongation ranged from $50 \%$ of controls for the 17 June treatment to approximately $75 \%$ of controls by the 3 Aug. treatment (Table 3). The number of nodes produced was also depressed by early season application of $\mathrm{P}-\mathrm{Ca}$ (Table 3), mirroring the response in shoot length. The 'Delicious' trees were under sporadic water stress and moderate European red spider mite (Panonychus ulmi Koch) pressure, suppressing shoot growth across all treatments. Actively growing shoots appeared to respond to P-Ca by setting terminal buds, but other stresses encouraged early bud set on many shoots, resulting in no significant effects of P-Ca on shoot length (Table 3). However, the total number of nodes produced on 'Delicious' shoots was reduced by P-Ca application between 17 June and 3 Aug.

The 'Fuji' at the same site as the 'Delicious' trees were also subject to European red mite and water deficit pressure, differences in shoot growth or node numbers were not statistically significant (Table 3). A high percentage of the 'Fuji' shoots established terminal buds before $\mathrm{P}-\mathrm{Ca}$ application.

In 'Macoun', P-Ca treatment on 17 June 1996 significantly depressed flowering the following spring on previous season's growth, but later treatments had no effect. Flowering, but not fruit set, on older wood was significantly increased by treatment on 17 Aug. (Table 3). No P-Ca affects on flowering or fruiting were observed in 'Fuji' or 'Delicious'.

Table 1. The effects of P-Ca treatment $\left(250 \mathrm{mg} \cdot \mathrm{L}^{-1}\right)$ in 1996 on the percentage of terminal bud set achieved on leaders and lateral branches of nursery trees in 1996.

\begin{tabular}{|c|c|c|c|c|c|c|c|}
\hline \multirow[b]{2}{*}{ Cultivar } & \multirow{2}{*}{$\begin{array}{c}\text { Time of P-Ca } \\
\text { application }\end{array}$} & \multicolumn{2}{|c|}{16 Sept. } & \multicolumn{2}{|c|}{23 Sept. } & \multicolumn{2}{|c|}{30 Sept. } \\
\hline & & Lead. $^{\mathrm{z}}$ & Lat. $^{2}$ & Lead. & Lat. & Lead. & Lat. \\
\hline \multirow{2}{*}{ Fuji/M9 } & 1 Sept. & $0 \mathrm{a}$ & $60 \mathrm{a}$ & $90 \mathrm{~b}$ & $100 \mathrm{~b}$ & $100 \mathrm{~b}$ & $100 \mathrm{~b}$ \\
\hline & 1 Sept., 1 Oct. & $0 \mathrm{a}$ & $30 \mathrm{a}$ & $60 \mathrm{~b}$ & $70 \mathrm{ab}$ & $80 \mathrm{~b}$ & $100 \mathrm{~b}$ \\
\hline \multirow[t]{3}{*}{ Golden Delicious/M9 } & None & $0 \mathrm{a}$ & $60 \mathrm{a}$ & $0 \mathrm{a}$ & $100 \mathrm{a}$ & $10 \mathrm{a}$ & $100 \mathrm{a}$ \\
\hline & 1 Sept. & $0 \mathrm{a}$ & $40 \mathrm{a}$ & $80 \mathrm{~b}$ & $100 \mathrm{a}$ & $100 \mathrm{~b}$ & $100 \mathrm{a}$ \\
\hline & 1 Oct. & $0 \mathrm{a}$ & $40 \mathrm{a}$ & $0 \mathrm{a}$ & $80 \mathrm{a}$ & $20 \mathrm{a}$ & $80 \mathrm{a}$ \\
\hline
\end{tabular}

${ }^{\text {zLead. }}=$ leader, Lat. = lateral branches.

y Mean separation within columns and cultivars by LSD at $P \leq 0.05$.

Table 2. The effects of P-Ca treatment $\left(250 \mathrm{mg} \cdot \mathrm{L}^{-1}\right)$ in 1996 on the total nonstructural midwinter carbohydrate (sum of soluble and insoluble) concentration, nitrogen level, and shoot growth in 1997 of 'Fuji' and 'Golden Delicious' nursery tree shoots.

\begin{tabular}{|c|c|c|c|c|c|c|c|c|}
\hline \multirow{3}{*}{$\begin{array}{l}\text { Time of P-Ca } \\
\text { application }\end{array}$} & \multicolumn{4}{|c|}{ Fuji } & \multicolumn{4}{|c|}{ Golden Delicious } \\
\hline & \multirow{2}{*}{$\begin{array}{c}\mathrm{CHO}^{\mathrm{z}} \\
\left(\mathrm{mg} \cdot \mathrm{g}^{-1} \mathrm{DW}\right)\end{array}$} & \multirow{2}{*}{$\begin{array}{c}\mathrm{N} \\
(\% \mathrm{DW})\end{array}$} & \multicolumn{2}{|c|}{$\begin{array}{l}\text { Mean shoot growth } \\
(\mathrm{cm})\end{array}$} & \multirow{2}{*}{$\begin{array}{c}\mathrm{CHO} \\
\left(\mathrm{mg} \cdot \mathrm{g}^{-1} \mathrm{DW}\right)\end{array}$} & \multirow{2}{*}{$\begin{array}{c}\mathrm{N} \\
(\% \mathrm{DW})\end{array}$} & \multicolumn{2}{|c|}{$\begin{array}{c}\text { Mean shoot growth } \\
(\mathrm{cm})\end{array}$} \\
\hline & & & 1 June & 5 Aug. & & & 1 June & 5 Aug. \\
\hline None & 124 & 1.203 & 12.2 & 29.3 & 106 & 1.232 & 7.7 & 20.5 \\
\hline 1 Sept. & 120 & 1.357 & 11.3 & 31.6 & 174 & 1.341 & 10.7 & 23.9 \\
\hline 1 Oct. & 109 & 1.368 & 11.5 & 29.5 & 112 & 1.257 & 10.5 & 25.7 \\
\hline 1 Sept., 1 Oct. & 119 & 1.387 & 12.4 & 29.2 & 162 & 1.368 & 8.6 & 25.2 \\
\hline Control vs. all others & NS & $* * *$ & NS & NS & $* *$ & $* *$ & $*$ & $*$ \\
\hline
\end{tabular}

${ }^{\mathrm{z}} \mathrm{CHO}=$ carbohydrate.

ss, ********Nonsignificant or significant at $P \leq 0.05,0.01$, or 0.001 by analysis of variance. 
Table 3. The effects of P-Ca application $\left(250 \mathrm{mg} \cdot \mathrm{L}^{-1}\right)$ in 1996 on the mean lengths and the number of nodes of 1-year-old branches and on flowering and fruiting of three second-leaf apple cultivars in the subsequent growing season.

\begin{tabular}{|c|c|c|c|c|c|}
\hline \multirow[b]{2}{*}{$\begin{array}{l}\text { Time of P-Ca } \\
\text { application }\end{array}$} & \multirow[b]{2}{*}{$\begin{array}{l}\text { Length } \\
(\mathrm{cm})\end{array}$} & \multirow[b]{2}{*}{ No. nodes } & \multicolumn{2}{|c|}{ No. flower clusters on: } & \multirow[b]{2}{*}{$\begin{array}{c}\text { Total fruit/ } \\
\text { plant }\end{array}$} \\
\hline & & & $\begin{array}{l}\text { 1-year } \\
\text { wood }\end{array}$ & $\begin{array}{l}\text { Older } \\
\text { wood }\end{array}$ & \\
\hline \multicolumn{6}{|c|}{ Macoun } \\
\hline None & $55.7 \mathrm{de}^{\mathrm{z}}$ & $22.5 \mathrm{~cd}$ & $69.4 \mathrm{bc}$ & $54.1 \mathrm{a}-\mathrm{c}$ & 14.8 \\
\hline $6 / 17$ & $29.9 \mathrm{a}$ & $18.0 \mathrm{a}$ & $43.6 \mathrm{a}$ & $65.2 \mathrm{~b}-\mathrm{d}$ & 14.1 \\
\hline $7 / 3$ & $35.1 \mathrm{ab}$ & $18.5 \mathrm{ab}$ & $54.1 \mathrm{ab}$ & $69.0 \mathrm{~b}-\mathrm{d}$ & 15.6 \\
\hline $7 / 17$ & $39.3 \mathrm{~b}$ & $19.6 \mathrm{ab}$ & $64.5 \mathrm{bc}$ & $66.0 \mathrm{~b}-\mathrm{d}$ & 14.8 \\
\hline $8 / 3$ & $42.6 \mathrm{bc}$ & $22.2 \mathrm{~cd}$ & $75.2 \mathrm{c}$ & $73.7 \mathrm{~cd}$ & 14.7 \\
\hline $8 / 17$ & $47.9 \mathrm{~cd}$ & $20.7 \mathrm{bc}$ & $70.1 \mathrm{bc}$ & $74.5 \mathrm{~d}$ & 13.4 \\
\hline $9 / 3$ & 56.0 de & $22.5 \mathrm{~cd}$ & $68.7 \mathrm{bc}$ & $53.1 \mathrm{ab}$ & 15.6 \\
\hline $9 / 17$ & $\begin{array}{c}58.8 \mathrm{e} \\
* * *\end{array}$ & $\begin{array}{c}24.5 \mathrm{~d} \\
* * *\end{array}$ & $\begin{array}{c}58.1 \mathrm{a}-\mathrm{c} \\
*\end{array}$ & $\begin{array}{c}43.9 \mathrm{a} \\
*\end{array}$ & $\begin{array}{l}15.9 \\
\text { NS }\end{array}$ \\
\hline \multicolumn{6}{|c|}{ Delicious } \\
\hline None & $27.4 \mathrm{a}-\mathrm{c}$ & $27.4 \mathrm{bc}$ & 0.0 & 2.8 & 0.42 \\
\hline $6 / 17$ & $20.7 \mathrm{a}$ & $19.9 \mathrm{a}$ & 3.2 & 9.7 & 0.83 \\
\hline $7 / 3$ & $23.5 \mathrm{a}$ & $22.0 \mathrm{a}$ & 2.4 & 10.1 & 1.20 \\
\hline $7 / 17$ & $25.2 \mathrm{ab}$ & $22.0 \mathrm{a}$ & 3.4 & 8.1 & 1.70 \\
\hline $8 / 3$ & $25.8 \mathrm{ab}$ & $22.4 \mathrm{a}$ & 0.7 & 4.2 & 0.30 \\
\hline $8 / 17$ & $27.2 \mathrm{a}-\mathrm{c}$ & $23.6 \mathrm{ab}$ & 1.5 & 10.5 & 1.20 \\
\hline $9 / 3$ & $34.2 \mathrm{bc}$ & $26.4 \mathrm{bc}$ & 0.0 & 5.5 & 0.25 \\
\hline \multirow[t]{2}{*}{$9 / 17$} & $36.3 \mathrm{c}$ & $28.6 \mathrm{c}$ & 0.0 & 4.2 & 0.37 \\
\hline & $*$ & *** & NS & NS & NS \\
\hline \multicolumn{6}{|c|}{ Fuji } \\
\hline None & 19.5 & 15.6 & 14.0 & 17.9 & 4.9 \\
\hline $6 / 17$ & 19.5 & 15.7 & 10.6 & 11.2 & 4.7 \\
\hline $7 / 3$ & 14.2 & 16.2 & 21.0 & 21.0 & 5.9 \\
\hline $7 / 17$ & 18.7 & 17.9 & 17.6 & 9.0 & 5.5 \\
\hline $8 / 3$ & 12.3 & 14.9 & 21.5 & 17.1 & 6.7 \\
\hline $8 / 17$ & 11.5 & 17.1 & 21.0 & 12.5 & 4.6 \\
\hline $9 / 3$ & 19.4 & 14.4 & 18.5 & 15.9 & 5.5 \\
\hline \multirow[t]{2}{*}{$9 / 17$} & 21.8 & 18.5 & 11.5 & 15.0 & 2.7 \\
\hline & NS & NS & NS & NS & NS \\
\hline
\end{tabular}

${ }^{\mathrm{z}}$ Mean separation within columns and cultivars by LSD at $P \leq 0.05$.

Ns, ${ }^{*}, * * * *$ Nonsignificant or significant at $P \leq 0.05$ or 0.001 by analysis of variance..

\section{DISCUSSION}

Cool temperatures in late Summer 1996 caused early bud set in nursery trees, resulting in only modest differences between time of bud set in treated and control trees. Nonetheless, vegetative growth, carbohydrate concentration, and $\mathrm{N}$ levels were increased significantly in the shoots of 'Golden Delicious' trees treated with P-Ca (Table 2). While results appeared to support the hypothesis that improving levels of these nutrients would enhance tree growth, there was no correlation between vegetative growth of individual trees the following season and levels of nutrients measured at dormancy. Our data suggest that it may be possible to use P-Ca to enhance early vegetative growth of some apple cultivars, although the reason(s) for this is unclear, considering that $\mathrm{P}-\mathrm{Ca}$ is a growth retardant. Further research needs to be conducted to elucidate the cause and reproducibility of this enhancement and to determine if cultivars vary in response.

Terminal bud set occurred in leaders of treated trees, and in all 'Golden Delicious' laterals, only 3 weeks earlier than in nontreated controls. Larger differences in the time of terminal bud set might provide greater benefits in spring growth.

Prohexadione-Ca also reduced vegetative growth of actively growing shoots when applied prior to mid-August on second-leaf 'Macoun' trees (reduced shoot length and node formation) and 'Delicious' trees (reduced node formation only). This reduction was consistent with reported responses to other inhibitors of GA biosynthesis (Edgerton, 1986; Quinlan and Richardson, 1984; Williams, 1983), but resumption of growth in early-treated 'Macoun' demonstrates the more transient effect of P-Ca. No such reduction in shoot growth was evident in 'Fuji', probably because growth was less active at the time of application.

Inhibitors of GA biosynthesis can alter apple flowering and yield (Edgerton, 1986; Elfving and Cline, 1990; Elfving and Proctor, 1986; Estabrooks, 1993; Greene, 1986; Tymoszuk and Mika, 1986). How- ever, responses are variable, ranging from minor depressions in flowering and yield (Edgerton, 1986; Tymoszuk and Mika, 1986) to a near doubling of blossom cluster numbers and total yield per tree (Elfving and Cline, 1990; Estabrooks, 1993). In our trial, August P-Ca treatment increased 'Macoun' flowering 20\% overall and 35\% on older wood, but had no effect on fruiting (Table 3). In contrast, 'Delicious' and 'Fuji' did not respond. There was no benefit observed from P-Ca application to second-leaf trees in our experiment, and the reduced shoot growth observed may be deleterious in young trees by slowing development of mature canopy.

In addition to benefits in reducing pruning needs of mature apple trees (Greene, 1997), and possible benefits in production of nursery trees, P-Ca should be a useful tool for studying effects of photosynthate partitioning and GA on tree physiology. The 17 Aug. application of P-Ca to 'Macoun' increased flowering but did not significantly affect shoot length, suggesting that GA inhibition may be more important than nutrient availability in limiting flowering. Also, since $\mathrm{P}-\mathrm{Ca}$ affected flowering only in August, this may have been the period of peak flower initiation for these nonbearing trees. The rapid breakdown of P-Ca permits examination of temporal GA effects much more readily than is the case with more persistent inhibitors that have a sustained influence on GA metabolism.

\section{Literature Cited}

Abusrewil, G.S., F.E. Larsen, and R. Fritts, Jr. 1983. Pre- and post-storage starch levels in chemically and hand-defoliated Delicious apple nursery stock. J. Amer. Soc. Hort. Sci. 108:20-23.

Batjer, L.P. and M.N. Westwood. 1963. Effects of pruning, nitrogen, and scoring on growth and bearing characteristics of young Delicious apple trees. Proc. Amer. Soc. Hort. Sci. 82:5-10.

Chen, T.H.H., P. Murakami, P. Lombard, and L.H. Fuchigami 1991. Desiccation tolerance in bare-rooted apple trees prior to transplanting. J. Environ. Hort. 9:13-17.

Curry, E.A. and M.W. Williams. 1983. Promalin or $\mathrm{GA}_{3}$ increase pedicel and fruit length and leaf size of Delicious apples treated with paclobutrazol. HortScience 18:214-215.

Edgerton, L.J. 1986. Some effects of paclobutrazol on growth and fruiting of apple, peach, and cherry. Acta Hort. 179:467-472.

Elfving, D.C. and R.A. Cline 1990. Growth and productivity of vigorous 'Northern Spy'/ MM.106 apple trees in response to annually applied growth control techniques. J. Amer. Soc. Hort. Sci. 115:212-218.

Elfving, D.C. and J.T.A. Proctor 1986. Long-term effects of paclobutrazol (Cultar) on apple-tree shoot growth, cropping, and fruit-leaf relations. Acta Hort. 179:473-480.

Estabrooks, E.N. 1993. Paclobutrazol sprays reduce vegetative growth and increase fruit production in young McIntosh apple trees. Can. J. Plant. Sci. 73:1127-1135.

Evans, J.R., C.A. Ishida, C.L. Regusci, R.R. Evans, and W. Rademacher 1997. Mode of action, metabolism, and uptake of BAS-125W, prohexadione calcium. HortScience 32:557-558. (Abstr.)

Forshey, C.G. and D.C. Elfving 1987. The relationship between vegetative growth and fruiting in apple trees. Hort. Rev. 9:229-287.

Greene,D.W. 1986. Effect of paclobutrazol and analogs on growth, yield, fruit quality, and storage potential of 'Delicious' apples. J. Amer. Soc. Hort. Sci. 111:328-332.

Greene, G.M. 1997. The use of BAS-125 for apple production in the mid-Atlantic region. HortScience 32:558.

Larsen, F.E. and R. Fritts, Jr. 1986. Chemical defoliation of tree nursery stock with CuEDTA. HortScience 21:281-283.

Li, B.W., P.J. Schuhmann, and K.K. Stewart. 1982. Analysis of sugars and starch in foods: Methods and their limitations, p. 29. In: S. Reiser (ed.). Metabolic effects of utilizable dietary carbohydrates. Marcel Dekker, New York.

Marini, R.P., J.A. Barden, and D. Sowers. 1993. Growth and fruiting responses of 'Redchief Delicious' apple trees to heading cuts and scaffold limb removal. J. Amer. Soc. Hort. Sci. 118:446-449.

Parker, M.L. and E. Young. 1995. Leader management and soil fumigation affect branching and precocity of young apple trees. HortScience 30:1193-1195.

Peterson, A.B. and H. Hinman 1994. The economics of replanting apple orchards in Washington State. Acta Hort. 363:19-23.

Preston, A.P. 1978. Growth and cropping of two slow-to-bear cultivars on two very vigorous rootstocks. Hort. Res. 18:137-139.

Quinlan, J.D. and P.J. Richardson 1984. Effect of paclobutrazol (PP333) on apple shoot growth. Acta Hort. 146:105-111.

Rademacher, W. 1991. Inhibitors of gibberellin biosynthesis: Applications in agriculture and horticulture, p. 296-310. In: N. Takahashi, B.O. Phinney, and J. MacMillan (eds.). Gibberellins. Springer-Verlag, New York.

Steffens, G.L., J.T. Lin, A.E. Stafford, J.D. Metzger, and J.P. Hazebroek. 1992. Gibberellin content of immature apple seeds from paclobutrazol treated trees over three seasons. J. Plant Growth Regulat. 11:165-170.

Steffens, G.L. and S.Y. Wang 1986. Biochemical and physiological alterations in apple trees caused by a gibberellin biosynthesis inhibitor, paclobutrazol. Acta Hort. 179:433-442.

Tymoszuk, S. and A. Mika 1986. Growth control of apple trees with Cultar and Alar. Acta Hort. 179:195-198.

Westwood, M.N. 1993. Temperate-zone pomology. Timber Press, Portland, Ore.

Williams, M.W. 1983. Managing flowering, fruit set, and seed development in apple with chemical growth regulators, p. 273-286. In: W.J. Meudt (ed.). Strategies of plant reproduction. Beltsville Symp. No. 6. Granda Publishing, London. 